\title{
MUSIC IN THE TOURISM OFFERING OF RURAL REGIONS (THE CASE OF EASTERN CROATIA)
}

\author{
Elena Rudan ${ }^{1}$, Christian Stipanović ${ }^{2}$
}

Received 1 February, Revised 2 June 2021, Accepted 24 June 2021

Abstract: Music is an important element of a destination's integrated tourism product, especially in rural regions. This fact raises a variety of issues, in particular with regard to the tourism management of rural destinations. Answers are sought to questions on how music can be valorised to help create a distinctive tourism product, making it necessary to analyse the current state of the music offering before objectives can be set and concrete solutions, devised, to accomplish them. This paper explores the music offering of the rural regions of eastern Croatia and presents the results of a survey of the attitudes of destination managers (managers of tourist boards) in rural regions of eastern Croatia, with special emphasis on traditional music that is increasingly present and contributes to creating distinctive rural destinations (the valorisation of sound and music in the offering should also enhance the inclusion of music in promotion). The studied rural destinations of eastern Croatia are not developed in terms of tourism and their tourist accommodation capacities are very small. Music offering management, together with the valorisation and preservation of traditional values, could help them enhance their distinctiveness in the tourism market.

Key words: rural tourism, music, eastern Croatia, tourism development

Sažetak: Glazba čini jedan od važnih elemenata integralnog proizvoda destinacije i to osobito u ruralnim prostorima. $U$ tom smjeru otvaraju se različita pitanja i to osobito ona usmjerena turističkom menadžmentu ruralnih destinacija tj. odgovori na pitanje kako valorizirati glazbu u prepoznatljiv proizvod. Ponajprije pitanja u smjeru analize sadašnjeg stanja glazbene ponude koja omogućuje donošenja ciljeva i mogućih strategija u njihovoj realizaciji. Rad istražuje ponude glazbe ruralnih područja istočne Hrvatske (valorizacija zvuka glazbe u ponudi mora potencirati i uključivanje glazbe u promociji). U radu se prikazuju rezultati istraživanja stavova destinacijskog menadžmenta (direktora turističkih zajednica) ruralnih područja istočne Hrvatske o sadašnjem stanju upravljanja glazbom s posebnim naglaskom na tradicijsku glazbu koja je najprisutnija i koja doprinosi stvaranju prepoznatljivih ruralnih destinacija. Promatrane ruralne destinacije istočne Hrvatske nisu turistički razvijene s vrlo malim brojem smještajnih kapaciteta, stoga mogu svoju prepoznatljivost na turističkom tržištu

\footnotetext{
1 Elena Rudan, Ph.D., Associate Professor, University of Rijeka, Faculty of Tourism and Hospitality Management Opatija, Croatia, e-mail: elenar@fthm.hr, ORCID: 0000-0002-9958-3300

2 Christian Stipanović, Ph.D., Full Professor with tenure, University of Rijeka, Faculty of Tourism and Hospitality Management, Opatija, Croatia, e-mail: christis@fthm.hr, ORCID: 0000-0002-1424-0756
} 
ojačati baš upravljanjem glazbenom ponudom, ali $s$ valorizacijom i očuvanjem tradicijskih vrijednosti koja ona jednim dijelom posjeduje.

Ključne riječi: ruralni turizam, glazba, istočna Hrvatska, razvoj

\section{Highlights:}

- Qualitative trends in the tourism development of rural regions

- Opportunities for the valorisation of sound and (traditional) music in rural regions

- Analysis of music valorisation in the tourism of Eastern Slavonia

- Improving the valorisation of traditional music in the tourism offering and promotion

\section{Introduction}

Music is a component of an integrated tourist-destination product. Present in all parts of a tourism offering (music in accommodation and catering facilities, in wellness centres, concerts, festivals, evening entertainment, music in transportation vehicles, etc.), music gives added value to every offering in a destination, regardless of the specific form of tourism being developed. In their offerings and promotion, tourist destinations use various forms of music and sound that contribute to creating a specific destination experience, irrespective of the tourists' main motivation for travelling to a given destination. Rural regions are specific areas seeking to develop tourism based on their particular features and authenticity, and on the characteristics of rural spaces. Music, in particular the traditional music of a region as well as the traditional music of a specific locality, represents a distinctive feature of rural areas that can be used in developing all forms of rural tourism. According to Kušen (2002), music can become the greatest component of a given region's identity, although some types of music may not be pleasing to the ear of average domestic tourists, let alone foreign tourists. Some rural destinations have nonetheless managed to develop distinctiveness based on their traditional music, thus considerably enhancing the content and quality of their tourism offering (for example, Schrammelmusik in Austria). In such cases, music will remind tourists of their stay in such a destination and will evoke memories of the destination's heritage and values. To satisfy the overall needs of modern tourists, however, the music of a tourist destination should be viewed as the totality of all its forms, and should not be limited to traditional music, even though traditional music may be the most-widely found type of music in a rural region.

\section{Theoretical background}

\subsection{Tourism of rural regions}

Rural regions tend to develop their tourism offerings based on the specific natural and anthropogenic resources they possess. According to Čavrak (2003), modern trends and life-styles of urban populations - combined with ever-growing mobility and demand for diverse recreational and tourism services and facilities that centre on well-preserved natural resources, on tourism based on culture and cultural heritage, traditional national culture and art, folk customs and a traditional life-style, as well as rural tourism - are driving the development of a variety of activities that capitalise on these competitive advantages of rural regions. According to Svržnjak et al. (2014), the term "rural tourism" is an umbrella term for the activities and forms of tourism developed in rural areas. Grgić et al. (2017) argue that rural tourism is one of the solutions open to rural regions faced with depopulation (de-agrarianisation), low employment, and underdevelopment. Tourism development can help farmers sell their products and can boost the valorisation of cultural and historical heritage. Rural tourism includes a wide array of activities that are the bases for a broad range of tourism sub-forms in rural regions (for example, agritourism, food and wine tourism, eco-tourism, adventure tourism, hunting and fishing tourism, sport and recreational tourism, spiritual tourism, cultural tourism, creative tourism, etc.). Furthermore, the resource bases and activities in which tourists can participate make it possible 
to develop diverse forms of tourism, in particular forms that centre on autochthony and specific landscape features, as well as on the tangible and intangible elements of heritage that identifies the people of rural regions. Rudan \& Drpić (2019) suggest that the development of tourism products in a rural region must take into consideration the region's specific features while ensuring lasting protection of resource bases, fostering sustainable development, and improving the quality of the tourism offering.

Culture and heritage in rural regions are often well-preserved between generations and, in times of economic instability, heritage is safeguarded even more strongly. Culture and tourism then become a resource for socio-economic development in rural communities (MacDonald, Jolliffe, 2003). Remoaldo et al. (2017) pointed out that rural development must be underpinned by an inside-outside duality. They identified two development perspectives: one based on the mobilisation of local actors and resources (internal dimension) and the other based on the consolidation and establishment of a sales brand, which requires the commitment of policymakers (external dimension). The synergy of rural region development and tourism development implies cooperation among local residents, destination management, and local government and self-government. According to Krajnović, Čičin Šain \& Predovan (2011), rural tourism facilitates the conservation of the natural, and cultural and historical heritages of a host region, while reducing emigration and boosting the valorisation of the region's indigenous values. In any case, tourism development in rural regions brings about change. Figueiredo \& Raschi (2011) noted that the link between tourism and local context is not strong enough, and that the impact of tourism on local development is often limited to only a few sectors or groups, apparently without the ability to revitalise other, traditional activities. At the same time, tourism can exert pertinent influence in a rural context by bringing about vital changes in local attributes and character. Changes to the daily lives of residents (increase in living standards prior to the economic crisis caused by the coronavirus pandemic) together with tourism activities have the ability to change any space, including rural ones. The creation of a tourism product is vital when considering the development of tourist destinations in rural areas. Cooper and Hall (2008) claim that the development of new products is the main form of innovation in tourism and is essential for sector growth. Tourism products of rural regions provide experiences that can only be delivered within the specific spatial wholes they encompass.

Many forms of tourism can be developed in rural destinations. This paper focuses on one form, namely cultural tourism based on the tangible and intangible heritage that a destination possesses. In cultural tourism, the most important motivation to travel to a destination is to visit cultural attractions (history, art, heritage, etc.) that can meet cultural needs and interests. According to Pivčević \& Mandić (2012), the heritage a rural space possesses is in fact its most valuable tourism resource. The unique atmosphere, cultural and historical monuments, dynamic scenes of life in the streets, festivals and carnivals of destinations have always attracted visitors, and tourists have always shown an interest in learning more about a destination's tangible and intangible forms of culture. The food and wine offering is particularly important in rural regions as it enhances the experience of staying in a destination. Hence, traditional dishes prepared with indigenous foodstuffs make up a vital element of the offerings of tourist destinations in rural areas. Because tourists visiting a rural destination want to taste traditionally prepared food and beverages and buy local products, every part of a rural region's heritage can be valorised for tourism purposes through offering and promotion management. Novelties in tourism travel are linked to gastronomy, acquiring new knowledge, learning about the tradition and history (values) of the region visited, fulfilling spiritual desires, and communicating with local residents (Rudan, 2012). These changes on the demand side bring about changes in the regions where the supply side is located. As Bessiere (1998) stated, heritage valorisation represents not only a fashionable trend but also social, economic and political determination.

While the aim of tourists is to experience a rural destination and its values and identity, the degree to which tourists are motivated by culture to travel varies from one individual to another. Generally, culture is the primary travel motivation for the smallest share of tourists, as most tourists consider culture and heritage as being a supplementary offering to enjoy during their stay in a destination. How cultural tourism will be developed as a destination's tourism product depends on the diversity of the cultural tourism resource bases that a rural region possesses. A special feature are various 
events such as traditional festivals and gastronomic events. As Drpić \& Rudan (2019) pointed out, culture and heritage represent an important element in preserving traditions and strengthening local identity as preconditions to creating a permanently successful heritage-based tourism event and guaranteeing its sustainability in the market.

Croatia has a very diverse and varied distribution of natural and cultural resources that serve as a platform for developing tourism activities in different parts of the country. The pattern of tourism development, however, differs between areas along the coast and cities, and areas in rural regions, and this is reflected in uneven regional development. Smolčić Jurdana, Soldić Frleta \& Đedović (2018) underlined the need to identify resources in Croatia's rural regions and to know how to exploit them in order to ensure economic growth and the well-being of rural populations. In this respect, Dashper argues that rural tourism is not a magical solution to the problems faced by many rural areas, but it does offer opportunities for economic growth, social and cultural development, and enhancing community cohesion. Sudarić, Znaić and Deže (2018) noted that, based on a comparison of attractions and competitiveness, continental Croatia has the highest potential for cultural tourism, holiday-making in rural areas, and cycling tourism. They go on to state that rural tourism is an important factor in activating rural regions and ensuring their sustainable development, thus helping to preserve local identity, traditions and customs, protect the environment, strengthen indigenous, traditional and organic production, and foster the sustainability-based development of rural regions. As predispositions exist in continental Croatia for the development of rural tourism and the creation of a distinctive, well-designed and appealing tourism product, this paper seeks to define the cultural tourism of rural regions, and explores music as a primary element of the tourism product.

\subsection{Music in the tourism offering of rural regions}

Music and sound in tourism - in particular in the tourism of Croatia - is an under-researched field, making this a challenging topic for researchers. Some insights into the relationship between music and tourism can be found in papers from sociological, anthropological and ethnomusicological studies (Wrightson, 2000, Scott \& Selwyn, 2011; MacMillen, 2015; Baker, 2016; Bolderman, 2020). Tourism development can provide rural regions with opportunities for the valorisation of sound, in a broader sense (sound and getting in touch with nature; silence as opposed to the noise and bustle of cities), which can lead to the development of acoustic tourism, focused on designing offerings and products tied to aural experiences that are revealed in different forms of tourist attractions in destination presentation. (Schafer, 1997). Acoustic tourism reinforces the audio characteristics of a destination and, in turn, the offering of products that represent their destination symbolically, through sound. Music, as a narrower concept, correlates with music tourism as a sub-form of cultural tourism, in which music, as a travel motivation, is on an equal footing with art or architecture, and is seen as the carrier of a destination's identity and the main component of its exclusivity (Gortan-Carlin \& Orlić, 2014). Music tourism encompasses all types and forms of musical culture and practice. Music integrates well into creating experiences and tours that focus on cultural heritage, diversity, and local engagement. (UNWTO, 2018). Music constitutes an important part of every tourist stay in a rural destination, and it is often the most important element of an offering, the element that represents the destination in a unique way (Stipanović, Rudan \& Zubović, 2020). To satisfy the needs of tourists and visitors, tourist destination stakeholders seek to adjust musical forms to those needs. This involves activities ranging from playing different types of music in hospitality facilities to designing a primary offering based on a specific musical form. Each destination is looking to find its own way of meeting the needs of tourists to ensure a complete and different destination experience, thus becoming competitive in the modern tourism market. To achieve this, it is vital to understand tourists' needs as they can vary greatly, ranging from a casual interest in different musical forms (classical music, jazz, popular music, traditional music, etc.) to a desire to experience the music specific to the destination in which they are staying (the traditional music of a specific locality). It is also necessary to differentiate between the various forms of music usage (for example, concerts, music festivals, music parties, music workshops, musical visit tours, music/sound therapy (wellness), a gastronomic offering inspired by music/sound, etc.). Music has a huge impact on creating the mood of a tourism experience, and modern tourists want more than just a visual 
experience of a destination. The processes that take place when listening to music help to deepen a feeling of self, a sense of belonging to a community, and the experience of a destination (Waitt \& Duffy, 2010).

The special features of traditional music, and of the traditional music of a specific locality, help to boost the distinctiveness of rural tourist destinations in Croatia, as well as around the world. Local residents are proud of their traditional music, and so it becomes a part of a destination's integrated offering and is often present at gastronomic events, cultural events, festivals, etc. Song \& Yuan (2019) pointed out, however, that the authenticity of ethnic music is local, but not global. In rural regions, while traditional music is focused on interaction with folklore, customs, and a traditional lifestyle, it is also open to modern manners of interpretation. Traditional music is linked to rural regions and to an experience of indigenous values in which local residents are the promoters of their own culture, customs, tradition and music. Considerations arise regarding the communication, in digital form and largely via the Web, of traditional music as a part of cultural heritage. This is a fairly new field that opens up possibilities to study, and contribute to, the development of critical discourse concerning the application of new technologies in communicating traditional music (Tonković et al., 2014). In contrast, modern music and its subforms, adjusted to global values and tastes, are entering rural regions.

Issues concerning music management are emerging in rural destinations. It is not enough for music to merely exist; the music offering in tourism in rural destinations needs to be managed. There is no development model, however, and synergy among stakeholders is lacking. In addition, there is a lack of specific knowledge needed in the field of music, and funding is inadequate. Musical performances are often the result of the efforts of associations and individual enthusiasts wishing to present their traditional music. All in all, music in rural regions is poorly interpreted and insufficiently exploited in tourism development.

\section{Attitudes of destination managers towards music in Eastern Croatia}

\subsection{Methodology and findings}

In seeking to research the role of music in the music offerings of destinations, rural tourism destinations in particular, the authors of this paper did not come across any previous studies, making it necessary to conduct primary research on the role of music in rural regions, to ensure that music can become a sustainable and effective part of a destination's integrated product. The aim of research was to analysis the current state of music and sound in the rural tourism offerings of the rural regions of counties in eastern Croatia (Slavonia, the southern part of Baranja, and western Srijem), with the exclusion of city centres. These counties are Požega-Slavonia, Osijek-Baranja, Virovitica-Podravina, Brod-Posavina and Vukovar-Srijem. Located in the continental part of Croatia, these counties recorded a total of 261,322 tourist arrivals (table 1 ) and 498,260 overnights (table 2 ) in 2019 , accounting for $1.3 \%$ of total tourist arrivals and $0.55 \%$ of total overnights in Croatia (Croatian Bureau of Statistics, 2020). That these five counties have a total surface area of $12,486 \mathrm{~km}^{2}$, making up $22.06 \%$ of the territory of Croatia, suggests that tourism in that region is poorly developed, especially when compared with coastal destinations. The average number of overnights per tourist is 1.9 in eastern Croatia, but 4.6 at the national level. Table 1 and table 2 show there was consistent growth in the number of tourist arrivals and the number of overnights in destinations in eastern Croatia in the period 2015-2019. Overall, Osijek-Baranja County had the most overnights and Požega-Slavonia County, the least. 
Tab 1. Tourist arrivals, by county in eastern Croatia, in the period 2015-2019. Source: Authors' own construction, based on the Croatian Bureau of Statistics; First Release Tourist Arrivals and Nights in 2019, 2018, 2017, 2016 and 2015; and data of the Ministry of Tourism

\begin{tabular}{|l|c|c|c|c|c|}
\hline \multicolumn{1}{|c|}{ County } & 2015 & 2016 & 2017 & 2018 & 2019 \\
\hline Požega-Slavonia & 10,284 & 11,654 & 13,284 & 16,252 & 19,706 \\
\hline Osijek-Baranja & 79,588 & 89,060 & 92,239 & 99,025 & 107,598 \\
\hline Virovitica-Podravina & 11,308 & 12,789 & 14,184 & 18,023 & 16,710 \\
\hline Brod-Posavina & 23,991 & 26,569 & 28,614 & 34,500 & 36,759 \\
\hline Vukovar-Srijem & 51,566 & 69,818 & 88,942 & 80,536 & 80,549 \\
\hline Total & $\mathbf{1 7 6 , 7 3 7}$ & $\mathbf{2 0 9 , 8 9 0}$ & $\mathbf{2 3 7 , 2 6 3}$ & $\mathbf{2 4 8 , 3 3 6}$ & $\mathbf{2 6 1 , 3 2 2}$ \\
\hline
\end{tabular}

Tab 2. Tourist overnights, by county in eastern Croatia, in the period 2015-2019. Source: Authors' own construction, based on the Croatian Bureau of Statistics; First Release Tourist Arrivals and Nights in 2019, 2018, 2017, 2016 and 2015; and data of the Ministry of Tourism and Sport

\begin{tabular}{|l|c|c|c|c|c|}
\hline \multicolumn{1}{|c|}{ County } & 2015 & 2016 & 2017 & 2018 & 2019 \\
\hline Požega-Slavonia & 24,356 & 25,917 & 30,611 & 36,134 & 41,486 \\
\hline Osijek-Baranja & 158,226 & 172,945 & 177,677 & 194,904 & 217,692 \\
\hline Virovitica-Podravina & 28,909 & 30,840 & 33,453 & 46,299 & 44,744 \\
\hline Brod-Posavina & 42,889 & 46,031 & 50,791 & 55,775 & 60,030 \\
\hline Vukovar-Srijem & 94,519 & 102,201 & 138,470 & 132,042 & 134,308 \\
\hline Total & $\mathbf{3 4 8 , 8 9 9}$ & $\mathbf{3 7 7 , 9 3 4}$ & $\mathbf{4 3 1 , 0 0 2}$ & $\mathbf{4 6 5 , 1 5 4}$ & $\mathbf{4 9 8 , 2 6 0}$ \\
\hline
\end{tabular}

According to the survey TOMAS 2019 (2020) of the Institute for Tourism, the most common motivations for visiting continental Croatia are nature (32\%), touring $(26 \%)$, city break $(26 \%)$, sport and recreation (24\%), business (22\%), culture and art (16\%), hiking and villages (10\% each), gastronomy $(7 \%)$, events $(6 \%)$, and others. Tourists in continental Croatia are the most satisfied with the beauty of nature and landscapes $(89.3 \%)$, the beauty of towns $(87.5 \%)$, personal safety $(93.8 \%)$, and the hospitality of local residents $(91.1 \%)$, but are the least satisfied with the entertainment offering, services/facilities in the destination tailored to people with special needs, bicycles routes and trails, and information provided in protected nature areas.

To identify opportunities for enhancing the development of the tourism offering and promotion of Croatian destinations in rural regions, research was carried out on the role of music in tourism offerings. A survey, organised by the Faculty of Tourism and Hospitality Management in Opatija and the Croatian National Tourist Board, was conducted in April and May 2019 across the entire territory of Croatia. A total of 195 managers of the tourist boards of towns, municipalities and counties throughout Croatia responded to the designed questionnaire. Out of the total number of respondents, 21 were located in eastern Croatia (6 respondents in Virovitica-Podravina County; 5, in Brod-Posavina County; 5, in Osijek-Baranja County; 3, in Vukovar-Srijem County; and 2, in Požega-Slavonia). For the purpose of this paper, only destinations in eastern Croatia were taken into consideration. The questionnaire contained 24 questions, involving open-ended questions, item evaluation using a 5-point Likert scale, and ranking. The first set of questions referred to the importance of sound and music in tourism and the level of inclusion; the second set, to the valorisation of sound and music in the tourism offering, and the third set, to the valorisation of sound and music in tourism promotion. Statistical analysis was carried out in the Python application.

Results show that destination managers gave an average score of 3.5 to the overall tourism offerings of eastern Croatian destinations (with Osijek-Baranja County having the highest score of 4.0, followed by Požega-Slavonia County with 3.5, while the counties Virovitica-Podravina, Brod-Posavina and Vukovar-Srijem each had a score of 3.4). The level of inclusion of sound and music in the tourism offering received an average score of 3.7 (with the highest score of 4.3 in Osijek-Baranja County, followed by Vukovar-Srijem County with 4.1, Požega-Slavonia County with 3.5, Virovitica-Podravina County with 3.4, and Brod-Posavina with 3.2). The level of inclusion 
of sound and music in tourism promotion was rated with an average score of 3.4 (with the highest score of 4.1 in Osijek-Baranja County, followed by Požega-Slavonia County with 3.5, VukovarSrijem County with 3.4, Brod-Posavina County with 3.2, and Virovitica-Podravina County with 2.8). Table 3 shows that the traditional music specific to a given destination is the music most included in the tourism offerings of eastern Croatian destinations, followed by traditional music in second place, and popular Croatian music, in third. The most common forms of the music offerings are concerts and festivals.

Tab 3. Inclusion of music in the tourism offerings of destinations in eastern Croatian. Source: Authors' own construction, after Stipanović, C. \& Grgurić, D., Istraživanje sadašnjeg stanja upravljanja zvukom i glazbom u hrvatskom turizmu: Analiza stavova destinacijskog menadžmenta. Opatija, Zagreb: Fakultet za menadžment u turizmu i ugostiteljstvu, Hrvatska turistička zajednica

\begin{tabular}{|l|l|l|l|l|l|}
\hline Type of music & $\begin{array}{l}\text { Croatian } \\
\text { popular } \\
\text { music }\end{array}$ & $\begin{array}{l}\text { Foreign } \\
\text { popular } \\
\text { music }\end{array}$ & $\begin{array}{l}\text { Classical } \\
\text { music }\end{array}$ & $\begin{array}{l}\text { Traditional } \\
\text { music }\end{array}$ & $\begin{array}{l}\text { Traditional } \\
\text { music of a } \\
\text { specific } \\
\text { locality }\end{array}$ \\
\hline Požega-Slavonia & 3.5 & 3.0 & 4.5 & 4.5 & 4.5 \\
\hline Osijek-Baranja & 4.2 & 3.2 & 3.0 & 4.5 & 4.5 \\
\hline Virovitica-Podravina & 4.2 & 2.8 & 2.8 & 3.3 & 3.5 \\
\hline Brod-Posavina & 4.3 & 3.0 & 3.2 & 4.0 & 3.8 \\
\hline Vukovar-Srijem & 4.6 & 3.0 & 3.3 & 5.0 & 5.0 \\
\hline Average score & $\mathbf{4 . 1}$ & $\mathbf{3 . 0}$ & $\mathbf{3 . 4}$ & $\mathbf{4 . 3}$ & $\mathbf{4 . 3}$ \\
\hline
\end{tabular}

The study also focused on the common forms of music employed in the offerings of tourist destinations in eastern Croatia (table 4). Results show that the most commonly used forms are music festivals, followed by concerts and music/sound-inspired gastronomic offerings (which is clearly a significant sign), while the least employed are music/sound therapy (wellness) (the wellness offering is very poorly distributed in eastern Croatia), sound/musical installations, and musical visit tours.

Tab 4. Average scores for the representation of music forms in destination offerings. Source: Authors' own construction

\begin{tabular}{|l|l|l|l|l|l|l|l|l|l|}
\hline County & $\mathbf{1}$ & $\mathbf{2}$ & $\mathbf{3}$ & $\mathbf{4}$ & $\mathbf{5}$ & $\mathbf{6}$ & $\mathbf{7}$ & $\mathbf{8}$ & $\mathbf{9}$ \\
\hline $\begin{array}{l}\text { Požega- } \\
\text { Slavonia }\end{array}$ & 3.5 & 4.5 & 3.0 & 4.0 & 2.5 & 2.5 & 4.0 & 2.5 & 3 \\
\hline $\begin{array}{l}\text { Osijek- } \\
\text { Baranja }\end{array}$ & 3.8 & 4.3 & 2.8 & 2.5 & 1.5 & 1.3 & 3.0 & 1.8 & 2.6 \\
\hline $\begin{array}{l}\text { Virovitica- } \\
\text { Podravina }\end{array}$ & 4.2 & 4.0 & 2.0 & 2.3 & 1.2 & 1.0 & 1.0 & 1.0 & 1.8 \\
\hline $\begin{array}{l}\text { Brod- } \\
\text { Posavina }\end{array}$ & 3.6 & 3.8 & 3.6 & 2.2 & 2.2 & 1.4 & 2.6 & 2.2 & 2.0 \\
\hline $\begin{array}{l}\text { Vukovar- } \\
\text { Srijem }\end{array}$ & 4.3 & 3.7 & 1.7 & 2.3 & 1.7 & 1.3 & 2.0 & 2.0 & 1.7 \\
\hline $\begin{array}{l}\text { Average } \\
\text { score }\end{array}$ & $\mathbf{3 . 8}$ & $\mathbf{4 . 1}$ & $\mathbf{2 . 2}$ & $\mathbf{2 . 3}$ & $\mathbf{1 . 8}$ & $\mathbf{1 . 5}$ & $\mathbf{2 . 5}$ & $\mathbf{1 . 9}$ & $\mathbf{2 . 2}$ \\
\hline
\end{tabular}

1. Concerts, 2. Music festivals, 3. Music party, 4. Music workshops, 5. Musical visit tour, 6. Music/sound therapy (wellness), 7. Music/sound-inspired gastronomic offering, 8. Sound/musical installations, 9. Acoustically specific spaces.

Music festivals, many of which focus on folklore, are well established in destinations in eastern Croatia. These events showcase the destinations' rich cultural heritage as well as the pride of local residents (improvement of social quality of life). One of the most important traditional festivals in this region is the international folklore festival Đakovački vezovi (Embroideries of 
Đakovo). Held annually in the town of Đakovo since 1967, the festival celebrates the bećarac ${ }^{3}$, the sound of the tambura ${ }^{4}$, and traditional music. Another important event is Vinkovačke jeseni (Autumn in Vinkovci Festival), also a folklore festival, held in the town of Vinkovci since 1966. Recognising the importance of traditional music, the Croatian National Tourist Board, together with Google Arts\&Culture, presented and promoted in September 2020, 25 Croatian intangible traditions (Croatia: Hearts and Crafts) through four sections - knowledge of crafts, folk singing and dancing, celebrations, and food - to help reposition Croatia as a distinctive cultural destination. In the project, music is presented through video recordings of traditional music and traditional instruments. ${ }^{5}$

The inclusion of music in the tourism offering needs to be paralleled with the inclusion of music in innovating tourism promotion, to achieve a synergistic effect and, consequently, to design and interpret a more comprehensive tourism product of enhanced quality. The representation of music in a destination's promotional activities is also very important, as potential tourists will associate the music with the destination's autochthony and distinctiveness. The study shows that of the various possible forms - audio logos, audio souvenirs, musical performances in promotional purposes, audio-designed promotional material, and other forms of sound and music-based promotion - the most commonly employed is musical performances in promotional purposes, organised by tourist boards (table 5). Average scores indicate that other forms are negligible.

Tab 5. Respondents' average scores regarding the inclusion of music forms in promotion, by county. Source: Authors' own construction

\begin{tabular}{|l|l|l|l|l|l|}
\hline County & $\mathbf{1}$ & $\mathbf{2}$ & $\mathbf{3}$ & $\mathbf{4}$ & $\mathbf{5}$ \\
\hline Požega-Slavonia & 2.5 & 3 & 4 & 3.5 & 4 \\
\hline Osijek-Baranja & 1.7. & 1.7 & 4 & 1.7 & 2.3 \\
\hline Virovitica-Podravina & 1.7 & 1 & 2.7 & 1.7 & 1 \\
\hline Brod-Posavina & 2.6 & 2 & 3.4 & 1.8 & 1.4 \\
\hline Vukovar-Srijem & 1 & 1 & 4.3 & 1 & 1 \\
\hline Average score & 1.9 & $\mathbf{1 . 7}$ & $\mathbf{3 . 7}$ & $\mathbf{1 . 9}$ & $\mathbf{1 . 9}$ \\
\hline
\end{tabular}

1: audio logo; 2: audio souvenir; 3: musical performance in promotional purposes; 4: audio-designed promotional materials; 5 : other forms of sound and music-based promotion.

\subsection{Discussion}

While music is present in the tourism offering of rural destinations in eastern Croatia, its inclusion in the tourism offering and tourism promotion have not been managed in a way that would make it easily recognisable to tourists coming to these destinations, generally for short stays. Music in general and traditional music in particular need to become a component of the integrated tourism product of eastern Croatia's rural tourist destinations. Very often, musical programmes target mostly local residents who, by presenting their traditional values, help to preserve these values and make them sustainable (Stipanović, Rudan \& Zubović, 2020b). It is the authenticity of the music of rural regions, however, that contributes to making it distinctive in the tourism market. The authenticity of traditional music provides specific value to a tourist destination. With modern tourists being explorers seeking new experiences, music could indeed become the experience provided by rural destinations of eastern Croatia. Gortan-Carlin \& Orlić (2014) noted that true authenticity of content can help to ensure the quality of the tourism offering of a tourism-receiving country while making diversity and uniqueness its main attraction. For traditional music, as one of the possible segments of a cultural tourism offering, to become an attraction, it must be characteristic of the place or region where visitors or tourists are staying. In other words, it must

\footnotetext{
${ }^{3}$ bećarac is a folk song, in the form of a couplet of decasyllable lines with rhyming last words, performed at weddings, as well as at other celebrations, because the lyrics are humorous

${ }^{4}$ tambura is the best-known traditional string instrument in Croatia's heritage

5 https://www.htz.hr/hr-HR/press/objave-za-medije/veliki-projekt-googlea-i-htz-hrvatska-kultura-dostupna-je-cijelomsvijetu, accessed 20 October 2020
} 
be exclusive to a given destination. Tourism brings change to everything and causes changes in all segments of people's lives. In the music offering, the types of music and the way they are interpreted also change. The authors go on to say that the transformation of traditional culture is an inevitable process. The adaptation of traditions to the needs of tourists, resulting in economic profit for local residents, is a global trend evident in many developed tourist destinations. At issue here is authenticity, and the question of whether authenticity is essential or whether it is, in fact, unattainable, underscores the need for collaboration among ethnologists, (ethno)musicologists and tourism workers. Stipanović, Rudan \& Zubović (2019) argue that a threshold for the valorisation of traditional music needs to be set to prevent traditional music from losing its indigenous expression, when adapting to current global values (cultural sustainability must always take precedence over market profitability). Traditional music should be connected to other elements of a destination's offering (in particular with the gastronomic, and cultural and creative offerings) but also to promotion, as their study shows that music is under-utilised in tourist destination promotion activities. The content of an integrated tourism product should not clash with the local values of traditional music. It should also be emphasised that the synergistic action is needed of all stakeholders involved in creating a tourism offering - destination management organisations, cultural associations, local residents, and entrepreneurs in tourism and hospitality - to ensure the well-conceived inclusion of music in the tourism offering of rural destinations. Only through collaboration can synergistic action yield positive and competitive results.

\section{Conclusion}

The indigenous values of rural regions are increasingly becoming attraction factors in modern tourism. Rural regions are also becoming more appealing during the COVID pandemic due to epidemiological reasons, and safety as a tourist motivation. As the appeal of rural regions grows, so does the importance of their music resources. Music evokes emotions linked to a stay in a tourist destination. The constant change in tourism supply and demand makes it necessary for little-known rural regions, seeking to develop a tourism offering, to focus on designing an integrated tourism product that includes intangible as well as tangible values. The results of the study confirm that the studied tourist destinations of eastern Croatia fail to employ music and sound to any significant extent in tourism. They also fail to valorise the potential of traditional music, in particular, as a unique resource in creating a distinctive offering and building destination identity. A precondition to the well-conceived and sustainable inclusion of music in general and traditional music in particular in the offering of rural destinations is the synergistic action of all stakeholders involved in designing a tourism offering (destination management organisations, local residents, cultural associations, entrepreneurs, etc.). Clearly, music management in the tourism offering should be integrated with all other forms of the offering, such as the food and wine offering, events (festivals, etc.) and the cultural and creative offering. It is essential to put in place a dynamic management model and foster a mindset focused on valorising different resources to create a novel music offering and promotion, with emphasis on the valorisation of the traditional music of one's own locality and on digitalisation and new technologies, to help differentiate and assert not only indigenous values and sustainable development but also all other forms and types of music targeting specific segments (the synergy of localisation and globalisation).

A limitation of this study is that it focuses only on destination management. Further research should seek to include other stakeholders - tourists and local residents - to establish how to integrate music into the tourism of rural regions to enable rural tourism destinations to create a distinctive offering.

\section{Acknowledgements}

This research was supported by the University of Rijeka within the framework of the project No. UNIRI-DRUSTV- 18-39 "The role of audio management in tourist destination development". 
[1] Bessiere, J. (1998). Local development and heritage; traditional food and cuisine as tourist attractions in rural areas. Sociologia Ruralis 39(1), 21-34. DOI: 10.1111/1467-9523.00061.

[2] Bolderman, L. (2020). Contemporary Music Tourism a Theory of Musical Topophilia. Abingdon-on-Thames: Routledge.

[3] Cooper, C. \& Hall, C. M. (2008). Contemporary tourism: an international approach. Oxford: Butterworth-Heinemann.

[4] Čavrak, V. (2003). Održivi razvoj ruralnih područja Hrvatske, Zbornik Ekonomskog fakulteta u Zagrebu 1(1), 61-77.

[5] Dashper, K. (2014). Introduction: Rural tourism: Opportunities and challenges. In Dashper, K., ed., Rural tourism: An international perspective (pp. 1-19). Cambridge: Cambridge Scholars Publishing.

[6] Drpić, D. \& Rudan, E. (2019). Event Competitivness in Heritage Tourism in Rural Croatia. Academica Turistica, 12(2), 161-172. DOI: 10.26493/2335-4194.12.161-172.

[7] Gortan Carlin, I. P. \& Orlić, I. (2014). Ponuda i potražnja autentičnosti u glazbenoturističkom doživljaju Istre: ceste glazbenotradicijskih manifestacija. Problemi sjevernog Jadrana, 13, 117-140.

[8] Grgić, I., Hadelan, L., Krznar, S. \& Zrakić, M. (2017). Could rural tourism revitalize rural areas in Croatia? Agroeconomia Croatia, 7(1), 98-108.

[9] Figueiredo, E. \& Raschi, A. (2011). Un' immensa campagna avvolta dal verde» - reinventing rural areas in Italy through tourism promotional images. European Countryside, 3(1), 1-20. DOI: 10.2478/v10091-011-0001-4.

[10] Krajnović, A., Čičin-Šain, D. \& Predovan, M. (2011). Strateško upravljanje razvojem ruralnog turizma - problemi i smjernice. Oeconomica Jadertina, 1(1), 30-45.

[11] Kušen, E. (2002). Turistička atrakcijska osnova, Zagreb: Institut za turizam.

[12] MacDonald, R. \& Jolliffe, L. (2003). Cultural rural tourism: Evidence from Canada. Annals of Tourism Research, 30(2), 307-322. DOI: 10.1016/S0160-7383(02)00061-0.

[13] Pivčević, S. \& Mandić, A. (2012). Potencijal turizma u revitalizaciji ruralnih područja uz očuvanje i valorizaciju zavičajne baštine, In: Sambi, N., ed., V. jubilarna međunarodna znanstveno-stručna konferencija - zavičajna baština, edukacija i održivi razvoj (pp. 205224). Split: Književni krug.

[14] Remoaldo, P., Freitas, I., Matos, O., Lopes, H., Silva, S., Sánchez Fernández, M. D., Cadima Ribeiro, J. \& Ribeiro, V. (2017). The Planning of Tourism on Rural Areas: The Stakeholders' Perceptions of the Boticas Municipality. European Countryside, 9(3), 504-525. DOI: 10.1515/euco-2017-0030.

[15] Rudan, E. (2012). Razvojne perspektive kreativnoga turizma Hrvatske. Ekonomska misao I praksa, 2012, 2, 713-730.

[16] Schafer, R. M. (1997). The Sonic Environment and the Tunning of the World: The Soundscape. Vermont: Destiny books.

[17] Scott, J. \& Selwyn, T., eds. (2011). Thinking through Tourism. Oxford: Berg.

[18] Smolčić Jurdana, D., Soldić Frleta, D. \& Đedović, L. (2018). Obilježja turizma u ruralnom prostoru. In: Smolčić Jurdana, D. \& Milohnić, I., eds., 4. međunarodni kongres o ruralnom turizmu, Novo vrijeme - vrijeme za ruralni turizam: zbornik radova (pp. 220-229). Opatija, Zagreb: Fakultet za menadžment u turizmu i ugostiteljstvu, Hrvatska udruga za turizam I ruralni razvoj "Klub članova selo". 
[19] Song, Y. \& Yuan, M. (2020). Tourism and its impact on dong traditional music and life in Xiaoguang, Journal of Tourism and Cultural Change. DOI: 10.1080/14766825.2019.1707839.

[20] Stipanović, C. \& Grgurić, D. (2019). Istraživanje sadašnjeg stanja upravljanja zvukom I glazbom u hrvatskom turizmu: Analiza stavova destinacijskog menadžmenta. Opatija, Zagreb: Fakultet za menadžment u turizmu i ugostiteljstvu, Hrvatska turistička zajednica.

[21] Stipanović, C., Rudan, E. \& Zubović, V. (2019). Valorizacija tradicijske glazbe u razvoju turizma Istre. In: Filiposki, O., Metodijeski, D. \& Zlatovic, D., eds., Proceedings of the 4th International Conference The Challenges of Today (pp. 305-315). Šibenik: Polytechnic of Sibenik.

[22] Stipanović, C., Rudan, E. \& Zubović, V. (2020a). Trendovi glazbene ponude u hrvatskom turizmu. In Katalinić, B. \& Zima, D., 7th International Conference "Vallis Aurea" 2020. (pp. 631-639). Požega, Vienna: Polytehnic of Požega, DAAM International Vienna.

[23] Stipanović, C., Rudan, E. \& Zubović, V. (2020b). The role of traditional music in tourist destination development. In Črnjar, K., Smolčić Jurdana, D., eds., Tourism \& Hospitality Industry 2020. Trends and Challenges (289-301). University of Rijeka.

[24] Sudarić, T., Zmaić, K. \& Deže, J. (2018). Identifikacija i vrednovanje činitelja razvoja rurlanog turizma istočne Hrvatske. In Smolčić Jurdana, D. \& Milohnić, I., eds., Novo vrijeme - vrijeme za ruralni turizam: zbornik radova (267-277). Opatija, Zagreb: Fakultet za menadžment u turizmu i ugostiteljstvu, Hrvatska udruga za turizam i ruralni razvoj "Klub članova selo".

[25] Svržnjak, K., Kantar, S., Jerčinović, S. \& Kamenjak, D. (2014). Ruralni turizam: uvod u destinacijski menadžment. Križevci: Visoko gospodarsko učilište.

[26] Marušić, Z. ed. (2020). Tomas 2019: stavovi i potrašnja turista u Hrvatskoj. Zagreb: Institut za turizam.

[27] Tonković, Ž., Krolo, K. \& Marcelić, S. (2014). Kulturna potrošnja i glazbene preferencije mladih: razvoj tipologije na primjeru Zadra. Revija za sociologiju, 44(3), 287-315. DOI: $10.5613 /$ rzs.44.3.3.

[28] Vaz, M., Dinis, A. \& Silva, O. (2017). New rurality, traditional music and tourist experiences. Journal of Tourism, Heritage \& Services Marketing, 3(1), 25-32. DOI: $10.5281 /$ zenodo.401373.

[29] Waitt, G. \& Duffy, M. (2010). Listening and tourism studies. Annals of Tourism Research, 37(2), 457-477. DOI: 10.1016/j.annals.2009.10.017.

[30] Wrightson, K. (2000). An Introduction to Acoustic Ecology. Soundscape - The Journal of Acoustic Ecology. 1(1), 10-13.

Other sources

[31] Državni zavod za stitistiku. Priopćenja dolasci i noćenja turista u 2019, 2018, 2017, 2016 i 2015. Zagreb: Državni Zavod za statistiku. www.dzs.hr (20.9.2020).

[32] Đakovački vezovi, https://djakovacki-vezovi.hr/o-manifestaciji-djakovacki-vezovi/ (2.9.2020).

[33] Hrvatska turistička zajednica (2020). Veliki projekt googlea i htz-a: hrvatska kultura dostupna je cijelom svijetu, https://www.htz.hr/hr-HR/press/objave-za-medije/veliki-projekt-googlea-ihtz-hrvatska-kultura-dostupna-je-cijelom-svijetu (1.10.2020).

[34] Ministarstvo turizma (2020). Turistički promet, https://mint.gov.hr/pristupinformacijama/dokumenti-80/statistike/arhiva-12059/12059 (1.10.2020).

[35] Music in Austria, https://press.austria.info/us/about-austria/background-information/musicin-austria/ (10.10.2020). 
[36] FolkColud (2020). Traditional / folk music of Croatia, https://folkcloud.com/folk-music-bycountry/croatia (10.11.2020).

[37] UNWTO (2018). Music is the new gastronomy: white paper on music and tourism - your guide to connecting music and tourism, and making the most out of it. Bogota: Sound Diplomacy and ProcColombia.

[38] Vinkovačke jeseni, http://vinkovackejeseni.hr/ (15.10.2020). 